\title{
Ecology of the invasive Asian clam Corbicula fluminea (Müller, 1774) in aquatic ecosystems: an overview
}

\author{
R. Sousa ${ }^{1,2}$, C. Antunes ${ }^{1,3}$ L. Guilhermino ${ }^{1,2}$ \\ ${ }^{1}$ CIMAR/CIIMAR - Centro Interdisciplinar de Investigação Marinha e Ambiental - Universidade do Porto, Rua dos Bragas 289, 4050-123 \\ Porto, Portugal. E-mail: ronaldo.sousa@ciimar.up.pt \\ ${ }^{2}$ ICBAS - Instituto de Ciências Biomédicas de Abel Salazar - Universidade do Porto, Departamento de Estudos de Populações, Laboratório de \\ Ecotoxicologia, Lg. Prof. Abel Salazar 2, 4099-003 Porto, Portugal. \\ ${ }^{3}$ Aquamuseu do Rio Minho - Parque do Castelinho, 4920-290 Vila Nova de Cerveira, Portugal.
}

The Asian clam Corbicula fluminea is one of the most invasive species in freshwater aquatic ecosystems. The rapid growth, earlier sexual maturity, short life span, high fecundity and its association with human activities makes $C$. fluminea a non-indigenous invasive species likely to colonize new environments. This species, originally distributed in Asiatic ecosystems, is now a common inhabitant of American and European freshwater habitats. The present paper reviews the information related to the life cycle, ecology and potential ecological and economic impacts caused by $C$. fluminea in the invaded habitats. Furthermore, this paper also proposed future works that may be implemented in order to increase our general knowledge about the ecology of this bivalve.

Keywords: Corbicula fluminea, life cycle, non-indigenous invasive species, ecological and economic impacts

\section{Introduction}

The accidental or deliberate introduction and subsequent spread of non-indigenous invasive species (NIS) has become a serious ecological, conservational and economic problem. These NIS are altering the terrestrial and aquatic ecosystems at unprecedented rates (Carlton \& Geller 1993, Lodge et al. 1998, Cox 2004) and are now one of the most important environmental problems concerning the scientific community (Sala et al. 2000). In fact, species diversity and distribution were never spatial or temporally stationary. However, in the last years species are being dispersed across their natural geographic barriers through human-mediated activities such as global trade, agriculture, aquaculture, recreational activities and transportation (Cohen \& Carlton 1998, Ricciardi \& MacIsaac 2000, Cox 2004).

Scientists interested in biological invasions have difficulties describing the fundamental characteristics responsible for the invasive success of some non-indigenous species, and the evolutionary and ecological principles behind the success of invasions in new environments have always been highly debated (Occhipinti-Ambrogi 2007). Generally, for invasive animal species the most important characteristics to be successful in the new habitat are: great geographical distribution with potential ability to colonize a vast range of habitats; considerable genetic variability and phenotypic plasticity; physiological tolerance to abiotic changes; short generation times, rapid growth, rapid sexual maturity and great fecundity; opportunistic behaviour (r-strategists); fertilized females able to colonize alone; and association with human activities and high dispersal potential (Lodge 1993, Alcaraz et al. 2005, Céréghino et al. 2005). However, the fundamental role of propagule pressure (i.e. introduction effort, which is related to the total number of individuals introduced in conjunction to the number of introductions attempts) is central to the success of NIS establishment and increases the probabilities of dispersion. Despite their significance, this hypothesis only recently gained a determinant importance in the biological invasion theory (Ruiz et al. 2000, Ruesink 2005, Colautti et al. 2006, Ricciardi 2007).

The Asian clam Corbicula fluminea is considered one of the most important faunal NIS in aquatic ecosystems. In the last few decades, studies of $C$. fluminea have shown both a considerable geographic dispersion and invasive behaviours (Mouthon 1981, Araujo et al. 1993, McMahon 2000). The invasive success and subsequent dispersion of $C$. fluminea relies more on their natural 
characteristics (e.g. rapid growth, earlier sexual maturity, short life span, high fecundity, extensive dispersal capacities and its association with human activities) than in its physiological tolerance (McMahon 2002). In fact, this NIS when compared, for example, with other freshwater bivalve species appears to be less tolerant to environmental fluctuations such as elevated temperatures, hypoxia, emersion, low $\mathrm{pH}$ and low calcium concentrations (Byrne \& McMahon 1994, McMahon 2000, Johnson \& McMahon 1998, McMahon \& Bogan 2001, Sousa et al. 2007b, 2008).

This paper revises the data available for $C$. fluminea discussing the general life cycle characteristics, the potential ecological and economic impacts caused in invaded habitats and proposes future works that may be implemented to increase our general knowledge about the ecology of this bivalve.

\section{Invasion history}

The original distribution of the Corbicula genus was confined, in the beginning of the last century, to Asia, Africa and Australia and since then it has dispersed worldwide (Mouthon 1981, Counts 1986, Araujo et al. 1993, Ituarte 1994, McMahon 2000). The first documented occurrence of this genus outside its original distribution was in the Pacific coast of United States in the 1920s, possibly being introduced by Chinese immigrants as a food resource (Counts 1981). Forty years later, its distribution extended to the Atlantic coast of the United States. In South America, this genus was first recognized around the 1970s (Ituarte 1994) and in Europe its presence was described for the first time by Mouthon (1981). Complicating the picture, species from the Corbicula genus were also present in the fossil record of North America and Europe before the last glaciation (Araujo et al. 1993). However, the specific classification of these fossil individuals is very difficult, a fact that may be easily understood considering the taxonomic problems that still exist (see below). Consequently, recent invasions could be seen as a re-colonization process of earlier habitats and not as a true invasion (Pfenninger et al. 2002). If this perspective is correct, it seems that only in the last decades this genus found the necessary conditions to re-colonize the earlier habitats, coupled with increased chances of re-colonization through the vector of human activities. Another alternative hypothesis is the possible retention and a subsequent dispersion of Corbicula specimens from refuge areas such as South European ecosystems which were not subjected to glaciations processes. However, given the present rate of dispersion it is difficult to understand the reason why the species did not begin the re-colonization from the refuge areas before (but see Karatayev et al. 2007) with the suggestion that the spread of freshwater NIS bivalves' species was not a continuous process, but somewhat punctuated by periods of rapid long distance spread).

The introduction and subsequent dispersion of $C$. $f l u$ minea in aquatic ecosystems is probably a result of various human activities (e.g. ballast water transport, food resource, utilization of specimens as fish bait, aquarium releases, transport of juveniles and/or adults as a tourist curiosity or the juvenile byssal attachment to boat hulls) (McMahon 2000, 2002, Darrigran 2002, Lee et al. 2005). Additionally, $C$. fluminea has extensive capacities for natural dispersion since the pediveliger and juveniles are passively transported by fluvial or tidal currents, being also transported on the feet or feathers of aquatic birds (Prezant \& Chalermwat 1984, McMahon 2000, 2002). This kind of natural transportation may have a fundamental importance in the magnitude of secondary introductions (Figuerola \& Green 2002, Green \& Figuerola 2005).

\section{Morphometry and genetics}

Considerable controversy exists about the number of Corbicula species present in European and American freshwater ecosystems, to which taxon they belong and where they originated (Pfenninger et al. 2002). This controversy is related to the complicated taxonomical classification in the Corbicula genus due to the marked variation in shell morphology, colour and reproductive biology (Komaru \& Konishi 1999, Rajagopal et al. 2000, Renard et al. 2000, Siripattrawan et al. 2000, Qiu et al. 2001, Park etal. 2002, Pfenningeretal. 2002, Park \& Kim 2003, Lee et al. 2005, Sousa et al. 2007a). In French and Dutch rivers, Renard et al. (2000) based on morphometric variation and genetic analysis described three morphotypes that were classified as $C$. fluminea, $C$. fluminalis and another species for which a specific name was not assigned (being referred as Corbicula spec.). The results of Pfenninger et al. (2002), with material collected in the River Rhine recognized the presence of two Corbicula lineages: one corresponding to $C$. fluminea and the other to Corbicula spec. as defined by Renard et al. (2000). Additionally, the results of Sousa et al. (2007a) show clear morphometric differences in individuals colonizing two adjacent Portuguese estuarine ecosystems, although the two populations share similar mitochondrial cytochrome $c$ oxidase subunit I gene (mtCOI) sequences that correspond to $C$. fluminea sensu Renard et al. (2000). However, the results obtained by Park \& Kim (2003) with specimens from the native dis- 
tribution range (and comparison with non-native mtCOI sequences) give additional information about the different lineages inside the Corbicula genus. According to these authors, $C$. fluminalis sensu Renard et al. (2000) belongs also to the freshwater Corbicula lineage. These results may introduce several changes in our knowledge about the Corbicula distribution in European ecosystems because we may have several lineages belonging to the freshwater clade [e.g. may be the same species: $C$. $f l u$ minea sensu Renard et al. (2000)] but with several races/ morphotypes with origin in Asia and/or North America. In American ecosystems the same controversy still exists and Siripattrawan et al. (2000), based in mtCOI gene analysis, established the presence of two species (classified as $C$. fluminea and $C$. leana). However, Lee et al. (2005) with a study conducted in 12 sites distributed for North and South American freshwater ecosystems do not attribute a specific name to the different morphotypes analysed. Given the actual confusion inside this thematic, all these morphometric and genetic complications have to be studied in the future in order to elucidate the number of species inside the Corbicula genus. These studies will also be very informative for the clarification of the routes of introduction and for the invasion dynamics management in future invaded ecosystems.

\section{Life cycle}

Species from the Corbicula genus comprise different reproductive modes which have been related to its large ecological spectrum (Morton 1986, Rajagopal et al. 2000, Korniushin \& Glaubrecht 2003). Additionally, several unusual features of reproductive biology, such as polyploidy, unreductional biflagellate sperm, androgenesis and clonality were observed in this genus (Komaru \& Konishi 1996, 1999, Komaru et al. 1997, Qiu et al. 2001).

C. fluminea (Fig. 1a) is generally described as a hermaphroditic species. The fertilization occurs inside the paleal cavity and larvae are incubated in branchial water tubes (Fig. 1b). However, studies done by Rajagopal et al. (2000) in the putative $C$. fluminalis (which is classified by Park \& Kim (2003) as another freshwater Corbicula morphotype) show that the specimens that colonized the River Rhine are dioecious (with $3 \%$ of hermaphrodites). Another interesting characteristic of this species deals with the embryonic nutrition of brooding individuals, which remain uncertain. According to Kraemer \& Galloway (1986) and Byrne et al. (2000), eggs of Corbicula are rich in nutrients that are essential for the developing embryos. Additionally, the interlamellar junctions of inner demibranchs in $C$. fluminea and $C$. australis were found to be modified, which presumably serve as alter-
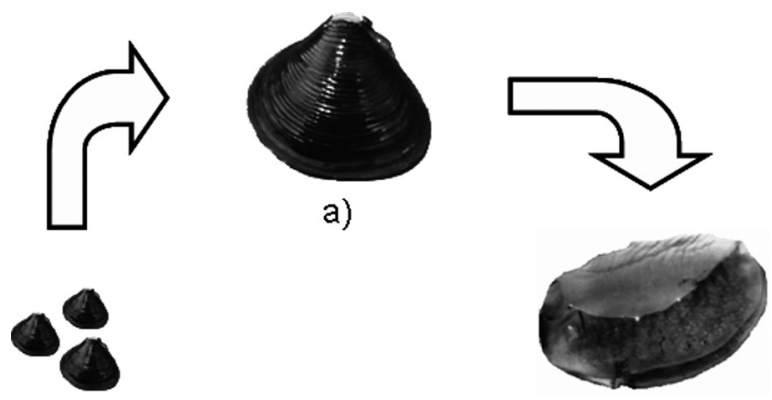

d)
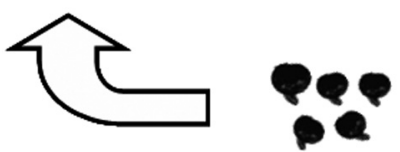

c)

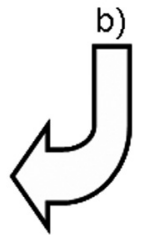

Fig. 1. Illustrative representation of the life cycle of $C$. fluminea: a) adult specimen; b) inner demibranch with larvae; c) small juveniles recently released (with a completely developed foot and with the common D-shaped configuration) and d) small adults.

native source of nutrition for embryos (Byrne et al. 2000). After this protective period, larvae are released into the water, settle and bury into the substratum (Cataldo \& Boltovskoy 1999, McMahon 2000). When C. flumine $a$ juveniles are released, they have small dimensions (around $250 \mu \mathrm{m}$ ) but completely formed with a well developed shell, adductor muscles, foot, statocysts, gills and digestive system and have the usual D-shaped configuration (Fig. 1c) (McMahon 2002). After the water column release, juveniles anchor to sediments, vegetation or hard surfaces due to the presence of a mucilaginous byssal thread. These juveniles can also be re-suspended by turbulent flows and dispersed for long distances, principally in the downstream direction (McMahon 2000). The maturation period occurs within the first 3 to 6 months when the shell length reaches 6 to 10 $\mathrm{mm}$ (Fig. 1d). The life span of this species is extremely variable, ranging from 1 to 5 years, with usual bivoltine juvenile release pattern (McMahon 2000). However, the number of annual reproductive periods changes from ecosystem to ecosystem. The majority of studies concluded that this species reproduces twice a year: one occasion in the spring going through the summer and the other starting in late summer and going through the autumn. In contrast, some studies found only one reproductive period, while in others three were found, with differences among years even in the same site (Doherty et al. 1987, Darrigran 2002). These fluctuations in the number of reproductive events may be related with water temperature (Hornbach 1992, Rajagopal et al. 2000, Mouthon 2001b) and/or with the food resources available in the 
ecosystem (Cataldo \& Boltovskoy 1999, Mouthon 2001a and b).

C. fluminea grows rapidly, in part due to its high filtration and assimilation rates (McMahon 2002). The major part of its energy is allocated to growth and reproduction and only a small portion is devoted to respiration (McMahon 2002). According to this author, this species has the highest net production efficiencies recorded for any freshwater bivalve, reflected by short turnover times of only $73-91$ days.

Like other freshwater bivalve species, C. fluminea transferred only a small percentage of assimilated energy to reproduction. Nevertheless, its elevated assimilation rates allow a high absolute energy transfer to reproduction when compared with other freshwater bivalves. $C$. fluminea has a high fecundity but a low juvenile survivorship and a high mortality rate throughout life span. This low adult survivorship leads to populations dominated by high proportions of juveniles (McMahon 2000, 2002). Anyway, in some ecosystems this population domination by immature juveniles is not so effective and the presence of adults in high abundance and having large sizes has been reported (Boltovskoy et al. 1997, Sousa et al. 2005, 2007b, 2008, in press, Cooper et al. 2007)

The principal life history characteristics of $C$. fluminea are summarised in Table 1.

\section{Possible ecological effects}

The introduction of NIS is a serious threat to the native biodiversity and ecosystem functioning with potential repercussions in food webs, biogeochemical cycles and human economy (Kolar \& Lodge 2001, Grosholz 2002).

The great invasive and reproductive capacity of $C$. $f l u$ minea makes this species an important component of aquatic ecosystems. Usually, C. fluminea introductions have consequences to other elements of the ecosystem including submerged vegetation, phytoplankton, zooplankton and higher trophic levels (Table 2) (Phelps 1994, Johnson \& McMahon 1998, Strayer 1999, Cherry et al. 2005, Cooper et al. 2005, Sousa et al. 2005, 2007b, 2008, in press). A revision of several studies shows that the invasion of $C$. fluminea has negatively impacted native bivalve abundance and diversity in North American and European freshwater ecosystems (Araujo et al. 1993, Williams et al. 1993, Strayer 1999, Aldridge \& Muller 2001, McMahon 2002, Sousa et al. 2005, 2006a, 2006b, $2007 \mathrm{~b}, 2008$, in press). The ancient bivalve fauna of European and North American rivers was dominated by freshwater mussels from the Margaritiferidae and
Unionidae families and small clams from the Sphaeriidae family. For example, the freshwater mussel species were very common in stable substrates but nowadays this ancient bivalve fauna is at risk in the principal European rivers (Reis 2003, Geist \& Kuehn 2005), being also of conservational concern in North American freshwater habitats (Lydeard et al. 2004, Strayer et al. 2004). In contrast, several worldwide freshwater ecosystems are now colonized by non-indigenous invasive bivalve species (e.g. C. fluminea, Dreissena polymorpha and Limnoperna fortunei) that replaced the native forms very quickly. The principal problem of the recent freshwater bivalve species invasions, such as $C$. fluminea, resides in the potential change in the ecological conditions of the invaded ecosystems. Corbicula species potentially affect native bivalve fauna in several ways: burrowing and bioturbation activity, principally at high abundances, may displace and/or reduce available habitats for juvenile unionids and sphaeriids (Vaughn \& Hakenkamp 2001); suspension and deposit feeding by Corbicula may negatively impact unionid juvenile recruitment (Yeager et al. 1994, Hakenkamp \& Palmer 1999); dense populations of Corbicula may ingest large numbers of unionids sperm, glochidia and newly metamorphosed juveniles (Strayer 1999); Corbicula may advantageously compete for food resources with sphaeriids and juvenile unionids since they have larger filtration rates, on a per biomass basis, than sphaeriids and unionids and consequently have the potential to limit planktonic food available to native bivalves (McMahon 1991). However, the reasons behind these negative impacts in the native fauna remain speculative and further manipulative research is needed to clarify these ecological interactions and impacts. Additionally, this invasive species can be a vector of introduction of new parasites and diseases to the biotic components of invaded ecosystems. Negative interactions with human activities have also been described after the introduction of this species (e.g. biofouling of water channels and raw water systems of factories and power stations and problems created for sand companies) (Darrigran 2002).

Positive effects (Table 2) are also expected to occur in invaded ecosystems since this species can provide habitats to other organisms (e.g. empty shells provide substrate or refuge for algae, gastropods, freshwater sponges, or other benthic species) (Crooks 2002, Gutiérrez et al. 2003) and be a new food resource for several pelagic and benthic species (Cantanhêde et al. 2008). Species from higher trophic levels are expected to consume $C$. fluminea and its high abundance and biomass may be a very important food source in many aquatic ecosystems. Fishes, birds and mammals are potential con- 
Table 1. Summary of the principal life history characteristics of $C$. fluminea

(adapted from McMahon, 2002).

\begin{tabular}{|c|c|}
\hline Life history characteristics & C. fluminea \\
\hline Life span & 1 to 5 years \\
\hline Age at maturity & 3 to 9 months \\
\hline Reproductive mode & Hermaphroditic \\
\hline Growth rate & Rapid \\
\hline Fecundity & 68678 \\
\hline Juvenile size release & $250 \mu \mathrm{m}$ \\
\hline Position of broods & Inner demibranchs \\
\hline Type of released larvae (juveniles) & D-shaped configuration \\
\hline Type of brooding & Synchronous \\
\hline Juvenile survivorship & Low \\
\hline Adult survivorship & Usually low \\
\hline Number of reproductive events & Usually two but may vary \\
\hline Assimilated energy respired & $11-42 \%$ \\
\hline Non-respired energy transferred to growth & $58-71 \%$ \\
\hline $\begin{array}{l}\text { Non-respired energy transferred to } \\
\text { reproduction }\end{array}$ & $5-15 \%$ \\
\hline Turnover time & 73 - 91 days \\
\hline Habitat requirements & $\begin{array}{l}\text { Intolerant to high salinity values and } \\
\text { even moderate hypoxia conditions } \\
\text { (this species is usually restricted to } \\
\text { well-oxygenated areas). Tolerate } \\
\text { low water temperatures and prefer } \\
\text { sandier sediments mixed with silt } \\
\text { and clay (which enhance the organic } \\
\text { matter content). However, in some } \\
\text { ecosystems this species can be } \\
\text { found in all types of sediments } \\
\text { (with or without submerged } \\
\text { vegetation) (Sousa et al. 2008) }\end{array}$ \\
\hline
\end{tabular}

sumers, although this perspective has not been fully exploited in ecological studies performed with this species in invaded habitats.

Repercussions on biogeochemical cycles are also expected and the classification of these impacts as positive or negative are very difficult and could depend on the specific characteristics of the invaded ecosystem. $C$. fluminea is a very efficient ecosystem engineer, altering the structure and function of invaded habitats (Crooks 2002, Karatayev et al. 2007). When bivalves are the major component of a certain habitat they strongly couple the benthic and water column environments, con- suming large amounts of primary producers, by filtering water at high rates. Through active feeding on particulate organic matter, filter-feeding bivalves can control phytoplankton standing stocks, primary production, water clarity, nutrient cycling, nature of food webs and sedimentation rates of particulate matter in habitats where they are abundant (Yamamuro \& Koike 1993, 1994, Gerritsen et al. 1994, Phelps 1994, Dame 1996, Ricciardi et al. 1997, Strayer et al. 1999, Nakamura \& Kerciku 2000, Gangnery et al. 2001, Kohata et al. 2003, Ruesink et al. 2005). C. fluminea is also recognized by their pedal feeding with consequential alterations in the abiotic characteristics of the top layer of the 
Table 2. Positive and negative effects that may occur after $C$. fluminea introduction.

\begin{tabular}{|c|c|}
\hline Positive effects & Negative effects \\
\hline $\begin{array}{l}\text { Shelter and substrate for other species } \\
\text { (Crooks 2002, Gutiérrez et al. 2003); }\end{array}$ & $\begin{array}{l}\text { Displace and/or reduce available habitat } \\
\text { for other species (Vaughn \& Hakenkamp } \\
\text { 2001); }\end{array}$ \\
\hline $\begin{array}{l}\text { Food resource for pelagic and benthic } \\
\text { species (Cantanhêde et al. 2008); }\end{array}$ & $\begin{array}{l}\text { Suspension and deposit feeding by } C \text {. } \\
\text { fluminea may negatively impact the }\end{array}$ \\
\hline $\begin{array}{l}\text { Reduce euthrophication processes due to } \\
\text { high filtration rates (Phelps 1994, } \\
\text { McMahon 2002); }\end{array}$ & $\begin{array}{c}\text { recruitment of other species (e.g. juvenile } \\
\text { unionids, sphaeriids) (Yeager et al. 1994, } \\
\text { Hakenkamp \& Palmer 1999); }\end{array}$ \\
\hline $\begin{array}{l}\text { Increase water clarity due to the high } \\
\text { filtration rates which may enhance the } \\
\text { submerged vegetation cover (Phelps }\end{array}$ & $\begin{array}{l}\text { Competition for benthic food resources } \\
\text { with other species (Sousa et al. 2005); }\end{array}$ \\
\hline \multirow[t]{5}{*}{$\begin{array}{c}\text { Bioindicator species for ecotoxicological } \\
\text { studies (Doherty 1990, Inza et al. 1997, } \\
\text { Cataldo et al. 2001b). }\end{array}$} & $\begin{array}{l}\text { High filtration rates, which can be } \\
\text { responsible to limit planktonic food to } \\
\text { other species and may ingest large } \\
\text { numbers of unionids sperm, glochidia } \\
\text { and newly metamorphosed juveniles } \\
\text { (McMahon 1991, Strayer 1999); }\end{array}$ \\
\hline & Vector of parasites and pathogens; \\
\hline & $\begin{array}{l}\text { Massive mortalities that eventually } \\
\text { occurred in specific environmental } \\
\text { conditions are disastrous for other biotic } \\
\text { components and may affect water quality } \\
\text { (Johnson \& McMahon 1998, Strayer } \\
\text { 1999, Cherry et al. 2005, Cooper et al. } \\
\text { 2005, Sousa et al. 2007b, 2008); }\end{array}$ \\
\hline & $\begin{array}{c}\text { Bioaccumulation and bioamplification of } \\
\text { contaminants (Narbonne et al. 1999, Tran } \\
\text { et al. 2001, Cataldo et al. 2001a and b, } \\
\text { Achard et al. 2004); }\end{array}$ \\
\hline & Biofouling (Darrigran 2002). \\
\hline
\end{tabular}

sediments. At the same time, there is growing evidence that bivalves also excrete large amounts of inorganic nutrients, mainly inorganic nitrogen, at the form of faeces and pseudofaeces (Asmus \& Asmus 1991). This release of nutrients can stimulate primary production by submerged vegetation and phytoplankton (Phelps 1994, Yamamuro \& Koike 1994, Dame 1996). Additionally, in some ecosystems and principally in summer months, the combination of several factors (e.g. increasing temperature, low flow conditions, decrease dissolved oxygen, the presence of great quantities of organic matter, decrease in the redox potential) may cause massive mortalities in benthic species, including C. fluminea (Johnson \& McMahon 1998, Strayer 1999, Cherry et al. 2005, Cooper et al. 2005, Sousa et al. 2007b, 2008). This occurrence can abruptly cause massive mortalities in all the benthic fauna, also affecting the water quality. Usually, the $C$. fluminea population rapidly recovers reaching previous abundance and distribution while native species usually take a long time to react (Sousa et al. 2007b, 2008). Therefore, this phenomenon could act in favour of $C$. fluminea and against native species, and may determine and/or accelerate the extirpation of some native species. 


\section{Corbicula fluminea as a freshwater bioindicator species}

In the last years the utilization of bivalves as bioindicator species became a common tool to assess biological impacts of some pollutants in estuarine and coastal areas. At the same time the use of bivalves in freshwater ecosystems for similar purposes has not been so common. The recent introduction of NIS in some ecosystems makes possible to utilize these species as bioincators because they have great abundance and possess good ecotoxicological characteristics. For example, the zebra mussel $D$.polymorpha has been frequently used to assess potential environmental impacts in freshwater ecosystems. $C$. fluminea seems to be a very interesting species from an ecotoxicological point of view because it has some appealing characteristics that could justified its use in this kind of studies, namely: $i$ ) this species has become a major component of benthic communities in several lotic and lentic habitats in different regions of the world and, thus, it has a wide spatial distribution; $i i)$ it may be found in both pristine and polluted environments iii) nowadays presents a very strong invasive dynamics in rivers, channels and lakes where it reaches very high abundance (Phelps 1994, Sousa et al. 2008); iv) this bivalve is easily maintained in the laboratory for several months and may be transplanted into field conditions using caging procedures (Cataldo et al. 2001a); v) this species has a great filtration capacity allowing the uptake of large amounts of pollutants, $v i$ ) several field studies have shown that $C$. fluminea is a good bioindicator of heavy metals or other contaminants (Doherty 1990, Inza et al. 1997, Cataldo et al. 2001b) and vii) the size of adults makes possible the dissection and separation of the main organs allowing specific analysis. The combination of all these traits and its ability to bioaccumulate and bioamplify several contaminants make $C$. flumine $a$ a very convenient model in ecotoxicology (Way et al. 1990, Bassack et al. 1997, Baudrimont et al. 1997a and b, 2003, Inza et al. 1997, Narbonne et al. 1999, Tran et al. 2001, Cataldo et al. 2001 a and b, Achard et al. 2004). Additionally, due to their ubiquitous distribution, this species can serve as a basis of worldwide comparisons of environmental monitoring data in freshwater ecosystems as the same manner as Mytilus spp. in marine environments.

\section{Conclusion and future studies}

C. fluminea is recognized as one of the most important invasive macrozoobenthic species in aquatic ecosystems, colonizing lentic and lotic habitats worldwide. The factors responsible for its great and successful invasive behaviour seem to reside further in their r-strategy and association with human activities than in great physiological capacities.

Given the large invasive potential of this NIS, it is essential to increase the research effort using new methodologies to reduce the negative impact of this NIS in invaded ecosystems, including in biodiversity (particularly in what concerns native bivalves of high conservational importance). General models trying to find patterns of distribution along large scales and establishing relationships between C. fluminea abundance and/or biomass and abiotic factors will be very informative for future risk analysis. Manipulative studies are also necessary in order to increase our knowledge about important ecological processes mediated by $C$. fluminea that can be responsible for changes in the ecosystem functioning (e.g. ecosystem engineering and facilitation processes, competition, parasitism, predation, filtration rates, secondary production). This information will be vital for the adoption of mitigation measures in early phases of the invasion and to reduce its negative ecological and economic impacts. In habitats where the presence of the species is effective, with great abundance and biomass, works on methods to eradicate or to control this NIS are needed to support management measures. As well, it is essential to minimize any form of transport of this species to other freshwater ecosystems not yet colonized. These situations are almost impossible to resolve, have large economic costs and potential tremendous impacts to the other biota components. However, in the last years some solutions like biological (Zavaleta et al. 2001) or chemical (Aldridge et al. 2006) management have arisen as a possible answer. Future studies have also to resolve some uncertainties in relation to the Corbicula genus taxonomy, as well as the origin, sources and pathways of dispersion. An international cooperation is crucial to complement these research efforts. For example, it is fundamental to complete genetic and phylogenetic studies in populations from different ecosystems around the world. Indeed, the systematic of hermaphroditic freshwater Corbicula lineages are extraordinarily complex and further research in this topic is necessary. A good cooperation between scientists from the $C$. fluminea native range with scientists from the invaded range will likely yield excellent and unexpected results. In reality, management programs, mitigation measures and eradication efforts on invasive species do only make sense when being undertaken by all affected countries (Gollasch 2007).

\section{Acknowledgments}

Ronaldo Sousa is supported by a PhD. grant from Portuguese Foundation for Science and Technology - FCT (SFRH/BD/18426/ 
2004). Special thanks are addressed to Eduardo Martins, Pedro Morais and Laura Page.

\section{References}

Achard M., Baudrimont M., Boudou A. \& Bourdineaud J.P. 2004. Induction of a multixenobiotic resistance protein (MXR) in the Asiatic clam Corbicula fluminea after heavy metal exposure. Aquat. Toxicol., 67, 347-357.

Alcaraz C., Vila-Gispert A. \& García-Berthou E. 2005. - Profiling invasive fish species: the importance of phylogeny and human use. Divers. Distrib., 11, 289-298.

Aldridge D.C. \& Müller S.J. 2001. - The Asiatic clam, Corbicula fluminea, in Britain: current status and potential impacts. $J$. Conchol., 37, 177-183.

Aldridge D.C., Elliott P. \& Moggridge G.D. $2006 . \quad-$ Microencapsulated BioBullets for the control of biofouling zebra mussels. Environ. Sci. Technol., 40, 975-979.

Araujo R., Moreno D. \& Ramos M.A. 1993. - The asiatic clam Corbicula fluminea (Müller, 1774) (Bivalvia: Corbiculidae) in Europe. Am. Malacol. Bull., 10, 39-49.

Asmus R.M. \& Asmus H. 1991. - Mussel beds: limiting or promoting phytoplankton? J. Exp. Mar. Biol. Ecol., 148, 215-232.

Bassack S.B., Oneto M.L., Verrengia Guerrero N.R. \& Kesten E.M. 1997. - Accumulation and elimination of pentachlorophenol in the freshwater bivalve Corbicula fluminea. B. Environ. Contam. Tox., 58, 497-503.

Baudrimont M., Andrès S., Durrieu G. \& Boudou A. 2003. - The key role of metallothionein in the bivalve Corbicula fluminea during depuration phase, after in situ exposure to $\mathrm{Cd}$ and $\mathrm{Zn}$. Aquat. Toxicol., 63, 89-102.

Baudrimont M., Lemaire-Gony S., Ribeyre F., Métivaud J. \& Boudou A. 1997b. - Seasonal variation of metallothionein concentrations in the Asiatic clam (Corbicula fluminea). Comp. Biochem. Physiol., 118, 361-367.

Baudrimont M., Métivaud J., Maury-Brachet R., Ribeyre F. \& Boudou A. 1997a. - Bioaccumulation and metallothionein response in the Asiatic clam (Corbicula fluminea) after experimental exposure to cadmium and inorganic mercury. Environ. Toxicol. Chem., 16, 2096-2105.

Boltovskoy D., Correa N., Cataldo D., Stripeikis J. \& Tudino M. 1997. - Environmental stress on Corbicula fluminea (Bivalvia) in the Paraná River Delta (Argentina): complex pollution-related disruption of population structures. Arch. Hydrobiol., 138, 483507.

Byrne M., Phelps H., Church T., Adair V., Selvakumaraswamy P. \& Potts J. 2000. Reproduction and development of the freshwater clam Corbicula australis in southeast Australia. Hydrobiologia, 418, 185-197.

Byrne R.A. \& McMahon R.F. 1994. - Behavioural and physiological responses to emersion in freshwater bivalves. Am. Zool., 34, 194-204.

Cantanhêde G., Hahn N.S., Gubiani É.A. \& Fugi R. 2008. Invasive molluscs in the diet of Pterodoras granulosus (Valenciennes, 1821) (Pisces, Doradidae) in the Upper Paraná River floodplain, Brazil. Ecol. Freshw. Fish, 17, 47-53.

Carlton J.T. \& Geller J.B. 1993. - Ecological roulette: the global transport of non-indigenous marine organisms. Science, 261, 78-83.

Cataldo D. \& Boltovskoy D. 1999. - Population dynamics of Corbicula fluminea (Bivalvia) in the Paraná river delta (Argentina). Hydrobiologia, 380, 153-163.

Cataldo D., Boltovskoy D., Stripeikis J. \& Pose M. 2001a. Condition index and growth rates of field caged Corbicula fluminea (Bivalvia) as biomarkers of pollution gradients in the
Paraná river delta (Argentina). Aquat. Ecosyst. Health Manage., 4, 187-201.

Cataldo D., Colombo J.C., Boltovskoy D., Bilos C. \& Landoni P. 2001b. - Environmental toxicity assessment in the Paraná river delta (Argentina): simultaneous evaluation of selected pollutants and mortality rates of Corbicula fluminea (Bivalvia) early juveniles. Environ. Pollut., 112, 379-389.

Céréghino R., Santoul F., Compin A. \& Mastrorillo S. 2005. - Using self-organizing maps to investigate spatial patterns of non-native species. Biol. Conserv., 125, 459-465.

Cherry D.S., Scheller J.L., Cooper N.L. \& Bidwell J.R. 2005. Potential effects of Asian clam (Corbicula fluminea) die-offs on native freshwater mussels (Unionidae) I: water-column ammonia levels and ammonia toxicity. J. N. Am. Benthol. Soc., 24, 369-380.

Cohen A.N. \& Carlton J.T. 1998. - Accelerating invasion rate in a highly invaded estuary. Science, 279, 555-558.

Colautti R.I., Grigorovich I.A. \& MacIsaac H. J. 2006. - Propagule pressure: a null model for biological invasions. Biol. Invasions, 8 , 1023-1037.

Cooper J.E. 2007. - Corbicula fluminea (Asian clam) in the Roanoke River, North Carolina: a stressed population? Southeast. Nat., 6, 413-434.

Cooper N.L., Bidwell J.R. \& Cherry D.S. 2005. - Potential effects of Asian clam (Corbicula fluminea) die-offs on native freshwater mussels (Unionidae) II: pore-water ammonia. J. N. Am. Benthol. Soc., 24, 381-394.

Counts C.L. 1981. - Corbicula fluminea (Bivalvia: Corbiculidea) in British Columbia. Nautilus, 95, 12-13.

Counts C.L. 1986. - The zoogeography and history of invasion of the United States by Corbicula fluminea (Bivalvia: Corbiculidae). Am. Malacol. Bull. Special Edition, 2, 7-39.

Cox G.W. 2004. - Alien species and evolution. Island Press, Washington, $377 \mathrm{p}$.

Crooks J.A. 2002. - Characterizing ecosystem-level consequences of biological invasions: the role of ecosystem engineers. Oikos, 97, 153-166.

Dame R.F. 1996. - Ecology of Marine Bivalves: an ecosystem approach. CRS Press, New York, $254 \mathrm{p}$

Darrigran G. 2002. - Potential impact of filter-feeding invaders on temperate inland freshwater environments. Biol. Invasions., 4, 145-156.

Doherty F.G. 1990. - The Asiatic clam, Corbicula spp, as a biological monitor in freshwater environments. Environ. Monit. Assess., 15, 143-181.

Doherty F.G., Cherry D.S. \& Cairns Jr. 1987. - Spawning periodicity of the Asiatic clam Corbicula fluminea in the New River, Virginia. Am. Midl. Nat., 117, 71-82.

Figuerola J. \& Green A. 2002. - Dispersal of aquatic organisms by waterbirds: a review of past research and priorities for future studies. Freshwater Biol., 47, 483-494.

Gangnery A., Bacher C. \& Buestel D. 2001. - Assessing the production and the impact of cultivated oysters in the Thau lagoon (Mediterranee, France) with a population dynamic model. Can. J. Fish. Aquat. Sci., 88, 1012-1020.

Geist J. \& Kuehn R. 2005. - Genetic diversity and differentiation of central European freshwater pearl mussel (Margaritifera margaritifera L) populations: implications for conservation and management. Mol. Ecol., 14, 425-439.

Gerritsen J., Holand A.F. \& Irvine D.E. 1994. - Suspension-feeding bivalves and the fate of primary production: an estuarine model applied to Chesapeake Bay. Estuaries, 17, 403-416

Gollasch S. 2007. - International collaboration on marine bioinvasions - the ICES response. Mar. Pollut. Bull., 55, 353-359. 
Green A. \& Figuerola J. 2005. - Recent advances in the study of long-distance dispersal of aquatic invertebrates via birds. Divers. Distrib., 11, 149-156.

Grosholz E. 2002. - Ecological and evolutionary consequences of coastal invasions. Trends Ecol. Evol., 17, 22-27.

Gutiérrez J.L., Jones C.G., Strayer D.L. \& Iribarne O.O. 2003. Mollusks as ecosystem engineers: the role of shell production in aquatic habitats. Oikos, 101, 79-90.

Hakenkamp C.C. \& Palmer M.A. 1999. - Introduced bivalves in freshwater ecosystems: the impact of Corbicula on organic matter dynamics in a sandy stream. Oecologia, 119, 445-451.

Hornbach D.J. 1992. - Life history traits of a riverine population of the Asian clam Corbicula fluminea. Am. Midl. Nat., 127, 248-257.

Inza B., Ribeyre F., Maury-Brachet R. \& Boudou A. 1997. - Tissue distribution of inorganic mercury, methilmercury and cadmium in the Asiatic clam (Corbicula fluminea) in relation to the contamination levels of the water column and sediment. Chemosphere, 35, 2817-2836.

Ituarte C.F. 1994. - Corbicula and Neocorbicula (Bivalvia: Corbiculidae) in the Paraná, Uruguay, and Rio de la Plata Basins. Nautilus, 107, 129-135.

Johnson P.D. \& McMahon R.F. 1998. - Effects of temperature and chronic hypoxia on survivorship of the zebra mussel (Dreissena polymorpha) and Asian clam (Corbicula fluminea). Can. J. Fish. Aquat. Sci., 55, 1564-1572.

Karatayev A.Y., Padilla D.K., Minchin D., Boltovskoy D. \& Burlakova L.E. 2007. - Changes in global economies and trade: the potential spread of exotic freshwater bivalves. Biol. Invasions, 9, 161-180.

Kohata K., Hiwatari T. \& Hagiwara T. 2003. - Natural water-purification system observed in a shallow coastal lagoon: Matsukawa-ura, Japan. Mar. Pollut. Bull., 47, 148-154.

Kolar C.S. \& Lodge D.M. 2001. - Progress in invasion biology: predicting invaders. Trends Ecol. Evol., 16, 199-204.

Komaru A. \& Konishi K. 1996. - Ultrastructure of biflagellate sperm in the freshwater clam Corbicula leana (Prime). Invertebr. Reprod. Dev., 29, 193-197.

Komaru A. \& Konishi K. 1999. Non-reductional spermatozoa in three shell colour types of the freshwater clam Corbicula fluminea in Taiwan. Zool. Sci., 16, 105-108.

Komaru A., Konishi K., Nakayama I., Koyabashi T., Sakai H. \& Kawamura K. 1997. - Hermaphroditic freshwater clams in the genus Corbicula produce non-reductional spermatozoa with somatic DNA content. Biol. Bull., 193, 320-323.

Korniushin A.V. \& Glaubrecht M. 2003. - Novel reproductive modes in freshwater clams: brooding and larval morphology in Southeast Asian taxa of Corbicula (Mollusca, Bivalvia, Corbiculidae). Acta Zool., 84, 293-315.

Kraemer L.R. \& Galloway M.L. 1986. - Larval development of Corbicula fluminea (Müller) (Bivalvia: Corbiculacea): an appraisal of its heterochrony. Am. Malacol. Bull., 4, 81-79.

Lee T., Siripattrawan S., Ituarte C. F. \& Ó Foighil D. 2005. Invasion of the clonal clams: Corbicula lineages in the New World. Am. Malacol. Bull., 20, 113-122.

Lodge D.M. 1993. - Biological invasions: lessons for ecology. Trends Ecol. Evol., 8, 133-137.

Lodge D.M., Stein R.A., Brown K.M., Covish A.P., Bronmark C., Garvey J.E. \& Klosiewki S.P. 1998 - Predicting impact of freshwater exotic species on native biodiversity: challenges on spatial scaling. Aust. J. Ecol., 23, 53-67.

Lydeard C., Cowie R.H., Ponder W.F., Bogan A.E., Bouchet P., Clark S.A., Cummings K.S., Frest T.J., Gargominy O., Herbert D.G., Hershler R., Perez K.E., Roth B., Seddon M., Strong E.E.
\& Thompson F.G. 2004. - The global decline of nonmarine mollusks. BioScience, 54, 321-330.

McMahon R.F. \& Bogan A.E. 2001. - Ecology and classification of North American freshwater invertebrates. Pages 331-429 in Mollusca: Bivalvia (2nd edition). Thorp J.H. \& Covich A.P. (eds). Academic Press, San Diego.

McMahon R.F. 1991. - Ecology and classification of North American freshwater invertebrates. Pages 315-399 in Mollusca: Bivalvia. Thorp J.H. \& Covish A.P. (eds). Academic Press, New York.

McMahon R.F. 2000. - Invasive characteristics of the freshwater bivalve Corbicula fluminea. Pages 315-343 in Nonindigenous Freshwater Organisms: Vectors, Biology and Impacts. Claudi R. \& Leach J. (eds). Lewis Publishers, Boca Raton.

McMahon R.F. 2002. - Evolutionary and physiological adaptations of aquatic invasive animals: r selection versus resistance. Can. $J$. Fish. Aquat. Sci., 59, 1235-1244.

Morton B. 1986. - Corbicula in Asia - an updated synthesis. Am. Malacol. Bull. Special Edition, 2, 113-124.

Mouthon J. 1981. - Sur la présence en France et au Portugal de Corbicula (Bivalvia, Corbiculidae) originaire d'Asie. Basteria, 45, 109-116.

Mouthon J. 2001 a. - Life cycle and populations dynamics of the Asian clam Corbicula fluminea (Bivalvia: Corbiculidae) in the Saone River at Lyon (France). Hydrobiologia, 452, 109-119.

Mouthon J. 2001 b. - Life cycle and population dynamics of the Asian clam Corbicula fluminea (Bivalvia: Corbiculidae) in the Rhône River at Creys-Malville (France). Arch. Hydrobiol., 151, 571-589.

Nakamura Y. \& Kerciku F. 2000. - Effects of filter-feeding bivalve on the distribution of water quality and nutrient cycling in a eutrophic coastal lagoon. J. Marine Syst., 26, 209-221.

Narbonne J.F., Djomo J.E., Ribera D., Ferrier V. \& Garrigues P. 1999. - Accumulation kinetics of polycyclic aromatic hydrocarbon adsorbed to sediment by the mollusc Corbicula fluminea. Ecotox. Environ. Safe., 42, 1-8.

Occhipinti-Ambrogi A. 2007. - Global change and marine communities: Alien species and climate change. Mar. Pollut. Bull., 55, 342-352.

Park J.-K. \& Kim W. 2003. - Two Corbicula (Corbiculidae: Bivalvia) mitochondrial lineages are widely distributed in Asian freshwater environment. Mol. Phylogenet. Evol., 29, 529-539.

Park J.-K., Lee J.-S. \& Kim W. 2002. - A single mitochondrial lineage is shared by morphological and allozymatically distinct freshwater Corbicula clones. Mol. Cells, 14, 315-322.

Pfenninger M., Reinhardt F. \& Streit B. 2002. - Evidence for cryptic hybridization between different evolutionary lineages of the invasive clam genus Corbicula (Veneroida, Bivalvia). $J$. Evolution. Biol., 15, 818-829.

Phelps H.L. 1994. - The Asiatic clam (Corbicula fluminea) invasion and system-level ecological change in the Potomac River Estuary near Washington, D.C. Estuaries, 17, 614-621.

Prezant R.S. \& Chalermwat K. 1984. - Flotation of the bivalve Corbicula fluminea as a means of dispersal. Science, 225, 1491-1493.

Qiu A., Shi A. \& Komaru A. 2001. - Yellow and brown shell colour morphs of Corbicula fluminea (Bivalvia: Corbiculidae) from Sichuan Province, China, are triploids and tetraploids. $J$. Shellfish. Res., 20, 323-328.

Rajagopal S., van der Velde G. \& bij de Vaate A. 2000. Reproductive biology of the Asiatic clams Corbicula fluminalis and Corbicula fluminea in the river Rhine. Arch. Hydrobiol., 149, 403-420. 
Reis J. 2003. - The freshwater pearl mussel [Margaritifera margaritifera $(\mathrm{L})$ ] (Bivalvia, Unionoida) rediscovered in Portugal and threats to its survival. Biol. Conserv., 114, 447-452.

Renard E., Bachmann V., Cariou M.L. \& Moreteau J.C. 2000. Morphological and molecular differentiation of invasive freshwater species of the genus Corbicula (Bivalvia, Corbiculidea) suggest the presence of three taxa in French rivers. Mol. Ecol., 9, 2009-2016.

Ricciardi A. \& MacIsaac H.J. 2000. - Recent mass invasion of the North American Great Lakes by Ponto-Caspian species. Trends Ecol. Evol., 15, 62-65.

Ricciardi A. 2007. - Are Modern Biological Invasions an Unprecedented Form of Global Change? Conserv. Biol., 21, 329-336.

Ricciardi A., Whoriskey F.G. \& Rasmussen J.B. 1997. - The role of zebra mussel (Dreissena polymorpha) in structuring macroinvertebrate communities on hard substrate. Can. J. Fish. Aquat. Sci., 54, 2596-2608.

Ruesink J.L. 2005. - Global analysis of factors affecting the outcome of freshwater fish introductions. Conserv. Biol., 19, 1883-1893.

Ruesink J.L., Lenihan H.S., Trimble A.C., Heiman K.W., Micheli F., Byers J.E. \& Kay M.C. 2005. - Introduction of non-native oysters: ecosystem effects and restoration implications. Annu. Rev. Ecol. Evol. Syst., 36, 643-89.

Ruiz G.M., Fofonoff P.W., Carlton J.T., Wonham M.J. \& Hines A.H. 2000. - Invasion of coastal marine communities in North America: apparent patterns, processes, and biases. Annu. Rev. Ecol. Evol. Syst., 31, 481-531.

Sala O.E., Chapin F.S., Armesto J.J., Berlow E., Bloomfield J., Dirzo R., Huber-Sanwald E., Huenneke L.F., Jackson R.B., Kinzig A., Leemans R., Lodge D.M., Mooney H.A., Oesterheld M., Poff N.L., Sykes M.T., Walker B.H., Walker M. \& Wall D.H. 2000. - Global biodiversity scenarios for the Year 2100. Science, 287, 1770-1774.

Siripattrawan S., Park J.-K. \& Ó Foighil D. 2000. - Two lineages of the introduced Asian freshwater clam Corbicula occur in North America. J. Mollus. Stud., 66, 423-429.

Sousa R., Antunes C. \& Guilhermino L. 2006b. - Factors influencing the occurrence and distribution of Corbicula fluminea (Müller, 1774) in the River Lima estuary. Ann. Limnol.-Int. J. Lim., 42, $165-171$.

Sousa R., Antunes C. \& Guilhermino L. 2007b. - Species composition and monthly variation of the Molluscan fauna in the freshwater subtidal area of the River Minho estuary. Estuar. Coast. Shelf. S., 75, $90-100$.

Sousa R., Dias S. \& Antunes C. 2006 a. - Spatial subtidal macrobenthic distribution in relation to abiotic conditions in the Lima estuary, NW of Portugal. Hydrobiologia, 559, 135 - 148.
Sousa R., Dias S., Freitas V. \& Antunes C. in press. - Subtidal macrozoobenthic assemblages along the River Minho estuarine gradient (NW of Iberian Peninsula). Aquat. Conserv. (DOI: 10.1002/aqc.871).

Sousa R., Freire R., Rufino M., Méndez J., Gaspar M., Antunes C. \& Guilhermino L. 2007a. - Genetic and shell morphological variability of the invasive bivalve Corbicula fluminea (Müller, 1774) in two Portuguese estuaries. Estuar. Coast. Shelf. S., 74, $166-174$.

Sousa R., Guilhermino L. \& Antunes C. 2005. - Molluscan fauna in the freshwater tidal area of the River Minho estuary, NW of Iberian Peninsula. Ann. Limnol. - Int. J. Lim., 41, 141 - 147.

Sousa R., Rufino M., Gaspar M., Antunes C. \& Guilhermino L. 2008. - Abiotic impacts on spatial and temporal distribution of Corbicula fluminea (Müller, 1774) in the River Minho Estuary, Portugal. Aquat Conserv., 18, $98-110$.

Strayer D.L. 1999. - Effects of alien species on freshwater molluscs in North America. J. N. Am. Benthol. Soc., 18, 74-98.

Strayer D.L., Downing J.A., Haag W.R., King T.L., Layzer J.B., Newton T.J. \& Nichols S.J. 2004. - Changing perspectives on Pearly Mussels, North America's most imperiled animals. BioScience, 54, 429-439.

Tran D., Boudou A. \& Masabuau J.C. 2001. - How oxygenation level influences cadmium accumulation pattern in the Asiatic clam Corbicula fluminea: a laboratory and a field study. Environ. Toxicol. Chem., 20, 2073-2080.

Vaughn C.C. \& Hakenkamp C.C. 2001. - The functional role of burrowing bivalves in freshwater ecosystems. Freshwater Biol., 46, 1431-1446.

Way C.M. \& Hornbach D.J. 1990. - Dynamics of filter feeding in Corbicula fluminea. Can. J. Zool., 68, 115-120.

Williams A.C., Warren M.L., Cumming K.S., Harris J.L. \& Neves R.J. 1993. - Conservation status of freshwater mussels of the United States and Canada. Fisheries, 18, 6-22.

Yamamuro M. \& Koike I. 1993. - Nitrogen metabolism of the filter-feeding bivalve Corbicula japonica and its significance in primary production of a brackish lake in Japan. Limnol. Oceanogr., 38, 997-1007.

Yamamuro M. \& Koike I. 1994. - Diel changes of nitrogen species in surface and overlying water of an estuarine lake in summer: evidence for benthic-pelagic coupling. Limnol. Oceanogr., 39, 1726-1733.

Yeager M.M., Cherry D.S. \& Neves R.J. 1994. - Feeding and burrowing behaviours of juvenile rainbow mussels Villoa iris (Bivalvia: Unionidae). J. N. Am. Benthol. Soc., 13, 217-222.

Zavaleta E.S., Hobbs R.J. \& Money H.A. 2001. - Viewing invasive species removal in a whole ecosystem context. Trends Ecol. Evol., 16, 454-459. 